\title{
The Routledge \\ Companion to Reinventing Management Education
}

Edited by Chris Steyaert, Timon Beyes and Martin Parker 
List of illustrations

1 Introduction: why does management education need reinventing?

Timon Beyes, Martin Parker and Chris Steyaert

\section{PART I}

Histories

2 The Carnegie Report: looking back and thinking forward William M. Sullivan, Thomas Ehrlich and Anne Colby

3 The test of time: historical perspectives on management education reform in the US

Ellen S. O'Connor

4 'Humanities' Business' and other narratives: how to read the future of management education?

Ulrike Landfester, Nicolaj Tofte Brenneche and

Queralt Prat-i-Pubill

5 Deschooling the manager through the humanities: Mintzberg's amateurish conscience

Nidhi Srinivas

6 Critical voices in management education in the UK

Linda Perriton and Amritesh Singh

7 A sociology of management in management education

Dirk Baecker 


\section{PART II}

\section{Philosophies}

8 Nietzsche as educator

Daniel Hjorth and Robin Holt

9 The art of relevation/revelation: a Whiteheadian approach to management education

Robert Chia and Ajit Nayak

10 Responsibility: Hans Jonas and the ethics of business

René ten Bos

11 They have escaped the weight of darkness: the problem space of Michel Serres

Steven D. Brown

12 Can management education practise Rancière?

Isabelle Huault and Véronique Perret

13 Doing management education with free jazz and Derrida

Mark Learmonth, Michael Humphreys and Martyn Griffin

\section{PART III}

\section{Concepts}

14 Management education in a pragmatist perspective after

Dewey's experimentalism

Ulrik Brandi and Bente Elkjaer

15 Thinking in and of the world: actualizing wisdom and pragmatism in business education?

Matt Statler and Perttu Salovaara

16 The art and practice of critique: the possibilities of critical psychodynamic education

Russ Vince

17 From creativity to imagination with Cornelius Castoriadis

Christian De Cock

18 What matters in sociomateriality: towards a critical posthuman pedagogy in management education

Tara Fenwick 
19 The practice-turn in management pedagogy: a cross-reading Silvia Gherardi

\section{PART IV}

Classrooms

$20 \mathrm{Re}$-envisaging leadership through the feminine imaginary in film and television

Emma Bell and Amanda Sinclair

21 Hacking the classroom: rethinking learning through social media practices

Götz Bachmann and Nishant Shah

22 Activism in business education: making the social sciences practical for social entrepreneurs Ester Barinaga

23 Spaces with a temper: on atmospheres of education Christoph Michels and Timon Beyes

24 Four voices: making a difference with art in management education Stefan Meisiek, Pierre Guillet de Monthoux, Daved Barry and Robert D. Austin

25 Playing and the performing arts: six memos for the future classroom

Chris Steyaert, Patrizia Hoyer and Bernhard Resch

PART V

Programmes

26 'Permission taking': the humanities and critical pedagogy in the MBA

Carl Rhodes

27 Knowledge you can't google: teaching philosophy at the business school Rasmus Johnsen, Morten Sorensen Thaning and Michael Pedersen

28 Liberal arts in business and business in liberal arts: the view from Bocconi

Paola Dubini and Elena Raviola 
29 Integrating humanities and social sciences: institutionalizing a contextual studies programme

Thomas S. Eberle and Jörg Metelmann

30 Survivors of an endangered species: doctoral programmes of the future

Barbara Czarniawska

31 The researcher's duties: continuing the conversation

Marton Racz

\section{PART VI}

\section{Futures}

32 Notes on feminist management education Alison Pullen

33 The fact of otherness: towards liberating the subaltern consciousness in contemporary management education Ajnesh Prasad

34 Engaging with the contradictions of capitalism: teaching 'sustainability' in the business school

Christopher Wright and Daniel Nyberg

35 Classroom diversity, infinite potential and the Bildung of debt Bent Meier Sorensen and Martyna Sliwa

36 'This is water': labours of division, institutions and history Martin Parker

37 Management education and the humanities: a future together? Bogdan Costea and Kostas Amiridis

38 Manners, taste and etiquette: new practices of 'politesse' in business and management

Damian O'Doherty 